NASZA DERMATOLOGIA Online OUR DERMATOLOGY Online

Source of Support: Nil

Competing Interests: None

\section{LOCALISED INVOLUTIONAL LIPOATROPHY: A CASE REPORT}

Kanthilatha Pai ${ }^{1}$, Sathish Pai ${ }^{2}$

${ }^{I}$ Department of Pathology, KMC International center, Manipal University, Manipal, India

2Department of Dermatology, KMC Manipal, Manipal University, Manipal, India

Corresponding author: Prof. Kanthilatha Pai

klpai@yahoo.com

\begin{abstract}
Localized involutional lipoatrophy (LIL) is a rare distinctive idiopathic form of localized lipoatrophy. The characteristic histopathologic feature of LIL are diminutive fat lobules composed of small adipocyte resembling fetal fat tissue. LIL is not a well-known disorder, there have been only a few reports on LIL in the English literature.We report a case of localised involutional lipoatrophy in a 25 year old lady with bilateral depressed lesions on both arms.
\end{abstract}

Key words: lipoatrophy; idiopathic; localized

\section{Introduction}

Localized involutional lipoatrophy (LIL) is a rare distinctive idiopathic form of localized lipoatrophy. It is characterized by loss of adipose tissue without antecedent inflammation and was first described by Peters and Winkelmann [1] in 1986. We present a case of LIL in a young lady who presented with features of bilateral LIL on both arms.

\section{Case report}

A 25 year old female presented with slowly occurring depressed depigmented lesions over both her arms. She had no other complaints. She was worried about the lesions for cosmetic reasons. On clinical examination there were bilateral, symmetrical, well demarcated depressed plaques measuring 2.5 x $2.0 \mathrm{cms}$ over the lateral aspect of both her arms. Overlying skin showed slight depigmentation (Fig. 1). No similar lesions were seen elsewhere in the body. She denied any history of trauma or injections to the site. She had no associated medical problems or history of drug intake. Her general physical examination and routine laboratory tests were within normal limits.

A skin biopsy from both depressed plaques showed a decrease in the number and size of adipocytes in the subcutaneous fat which was replaced by fibrocollagenous tissue, without any other significant findings in the epidermis or the dermis. There was no evidence of inflammation or increased vasculature (Fig. 2).

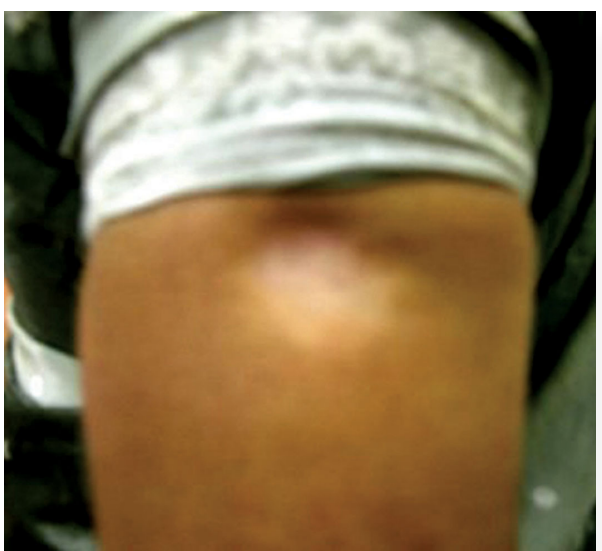

Figure 1. Depressed lesion over the forearm

\section{Discussion}

LIL has been defined as a focal loss of subcutaneous tissue on one or several sites, occurring without any significant trigger or autoimmune disease (hence their idiopathic nature). Most reported cases of idiopathic LIL have all been young women, except for a 5 year old boy who was the one exception [1]. 


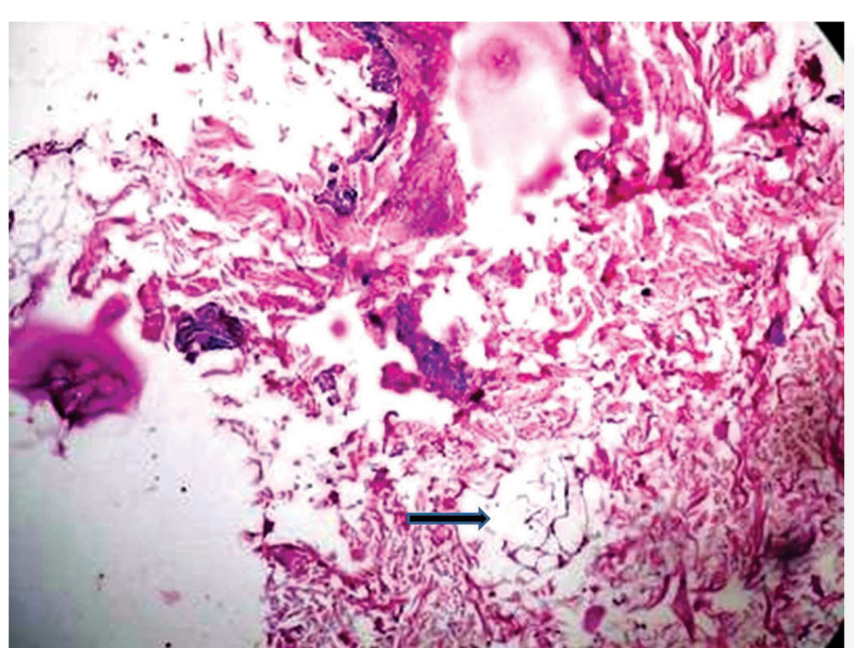

Figure 2. Photomicrograph of dimunitive subcutaneous fat lobules (shown by arrow) surrounded by fibrocollagenous tissue and no inflammation. (H\&E 100X)

Clinically, LIL presents as an asymptomatic, non-inflamed, well demarcated, localized, atrophic depression. The differential diagnoses of LIL include lupus erythematosus profundus [2], morphea [3], lichen sclerosus et atrophicus [3], and other types of lipoatrophy associated with triggers like repeated injections with corticosteroids and antibiotics [4-6] or sites of trauma [7]. These disorders can be differentiated from LIL based on the latter's characteristic histopathological feature, which is the presence of diminutive fat lobules composed of small adipocytes that resemble fetal fat tissue without the presence of inflammation. Due to lack of report on idiopathic LIL, the pathogenesis of idiopathic LIL remains unclear, and the female predominance is difficult to explain [8].

It is important to make an appropriate diagnosis of LIL and differentiate idiopathic LIL from lipoatrophy after drug administration or injury [8] and underlying immunological disorders and connective tissue diseases, such as systemic lupus erythematosus, nephritis, Sjögren syndrome, scleroderma, morphea, nephritis, hypocomplementemia, recurrent pyogenic infections, thyroiditis, and ITP.

Therefore, localized lipoatrophy should alert physicians to these diseases. Prompt and appropriate workup is necessary where clinically indicated.

Histopathological examination is the hallmark of diagnosis of LIL which shows dimunitive fat lobules with small lipocytes embedded in hyaline connective tissue absence of inflammatory cells, and myxoid stroma with numerous capillaries.

Treatment of lipoatrophy consists of reassuring the patient that the condition is benign. Anti-inflammatory drugs such as antimalarial or systemic steroids may be helpful in the early stage of the disease .If the lesions persist and are of cosmetic concern, localized fat transplantation may be performed. Our patient was reassured of the benign nature of the lesion and was treated with Chloroquine, $250 \mathrm{mg}$ once a day and topical tacrolimus ointment $0.1 \%$ twice daily. She was also advised to discontinue wearing tight fitting clothing, the pressure of which could have resulted in lipoatrophy.

\section{REFERENCES}

1. Peters MS, Winkelmann RK: The histopathology of localized lipoatrophy. Br J Dermatol. 1986;114:27-36.

2. Cendras J, Durand L, Dereure O: Idiopathic localized involutional lipoatrophy: a lupus profunds-like condition. Acta Derm Venereol. 2007;87:546-7.

3. Abbas O, Salman S, Kibbi AG, Chedraoui A, Ghosn S: Localized involutional lipoatrophy with epidermal and dermal changes. J Am Acad Dermatol. 2008;58:490-3.

4. Dahl PR, Zalla MJ, Winkelmann RK: Localized involutional lipoatrophy: a clinicopathologic study of 16 patients. J Am Acad Dermatol. 1996;35:523-8.

5. Yamamoto T, Yokozeki H, Nishioka K: Localized involutional lipoatrophy: report of six cases. J Dermatol. 2002;29:638-3.

6. Hisamichi K, Suga Y, Hashimoto Y, Matsuba S, Mizoguchi M, Ogawa H: Two Japanese cases of localized involutional lipoatrophy. Int J Dermatol. 2002;41:176-7.

7. Gruber PC, Fuller LC: Lipoatrophy semicircularis induced by trauma. Clinical \& Experimental Dermatology. 2001;26:269.

8. Lee YB, Kim JE, Park HJ, Cho BK: Two Cases of Idiopathic Localized Involutional Lipoatrophy Ann Dermatol. 2010;22:346-8.

Copyright by Kanthilatha Pai, et al. This is an open access article distributed under the terms of the Creative Commons Attribution License, which permits unrestricted use, distribution, and reproduction in any medium, provided the original author and source are credited. 